J. Clin. Chem. Clin. Biochem.

Vol. 14, 1976, pp. 527-532

\title{
Preparation of Parenchymal and Non-Parenchymal Cells from Adult Human Liver - Morphological and Biochemical Characteristics
}

\author{
By H. Bojar, Marianne Basler, F. Fuchs, R. Dreyfürst; W. Staib \\ Institut für Physiologische Chemie II (Direktor: Prof. Dr. W. Staib) der Universität Düsseldorf
}

and $C h$ Broelsch

Klinik für A bdominal- und Transplantationschirurgie (Direktor Prof. Dr. R. Pichlmayr) der Medizinischen Hochschule Hannover

(Received April 30/August 24, 1976)

Dedicated to Prof. Dr. L. Birkofer on the occasion of his 65 th birthday

Summary: By perfusion of the isolated human liver with collagenase and hyaluronidase a mixed suspension of various cell types was obtained. Pure parenchymal cells were prepared by differential centrifugation, pure non-parenchymal cells by the use of pronase and subsequent isopycnic centrifugation on metrizamide gradients $(50-300 \mathrm{~g} / \mathrm{l})$. About $90 \%$ of the parenchymal and non-parenchymal cells were viable as judged by trypan blue staining. Non-parenchymal cells were not capable of gluconeogenesis but utilized glucose at high rates. Parenchymal cells retained their ability to form glucose and to accumulate glycogen from fructose $>$ lactate/pyruvate $>$ alanine. Studies on binding of ${ }^{125}$ Ilabelled insulin by isolated parenchymal cells were performed at $30^{\circ} \mathrm{C}$. The binding data may fit a model with a minimum of two classes of binding sites: (a) high affinity - low capacity sites $\left(\mathrm{K}_{\mathrm{d}} \sim 6.6 \mathrm{nmol} / \mathrm{l}\right.$, capacity $\sim 16000$ insulin molecules per cell) and (b) low affinity - high capacity sites $\left(K_{d} \sim 0.37 \mu \mathrm{mol} / 1\right.$, capacity $\sim 646000$ molecules per cell).

\section{Präparation von Parenchym- und Nicht-Parenchymzellen aus der Leber des erwachsenen Menschen. Morphologische und biochemische Charakteristika}

Zusammenfassung: Durch Perfusion der isolierten menschlichen Leber mit Kollagenase und Hyaluronidase wurde eine heterogene Zellsuspension erhalten. Reine Parenchymzellen wurden durch Differentialzentrifugation gewonnen, reine Nichtparenchymzellen wurden mit Hilfe von Pronase und anschließender isopyknischer Zentrifugation auf Metrizamide-Gradienten (50-300 g/l) präpariert. Ungefähr 90\% der Pärenchym- und Nichtparenchymzellen waren nach dem Kriterium des Trypanblautestes vital. Nichtpärenchymzellen waren nicht zur Glukoneogenese befähigt, sondern utilisierten Glucose in hohen Raten. Parenchymzellen hatten ihre Fähigkeit zur Glukoneogenese und Glykogensynthese aus Fructose $>$ Lactat/Pyruvat $>$ Alanin bewahrt. Studien der Bindung von [ $\left.{ }^{125} \mathrm{~J}\right]$ Insulin durch isolierte Parenchymzellen wurden bei $30^{\circ} \mathrm{C}$ durchgeführt. Die Bindungsdaten können durch Annahme wenigstens zweier Klassen von Bindungsstellen interpretiert werden: (a) hochaffine Bindungsstellen mit geringer Kapazität $\left(\mathrm{K}_{\mathrm{d}} \sim 6,6 \mathrm{nmol} / \mathrm{l}\right.$, Kapazität $\sim 16.000$ Insulinmoleküle pro Zelle) und (b) geringeraffine Bindungsstellen mit hoher Kapazität $\left(\mathbf{K}_{\mathbf{d}} \sim 0,37 \mu \mathrm{mol} / 1\right.$, Kapazität $\sim 646000$ Moleküle pro Zelle).

\section{Introduction}

In recent years several enzymatic methods have been reported for the preparation of isolated parenchymal cells from rodent liver $(1-4)$. Collagenase either alone or in combination with hyaluronidase turned out to be the enzyyme of choice. As to non-parenchymal cells, a variety of techniques were employed to obtain pure cell suspensions from rodent liver (6-9). More recently, improved methods for the preparation of viable nonparenchymal cells from rat liver have been developed $(10,11)$, but no such techniques were available for human liver. Quiet obviously, it is much easier to isolate parenchymal cells from the soft liver of a young rat than from the firm liver of an adult human. Moreover, from animal experiments it is well-known that in some 
cases enzymatic procedures developed for one species cannot successfully be applied to another species without major modifications. Only small amounts of poorly characterized, more or less dedifferentiated epithelial cells can be obtained from primary cultures of liver fragments from adult human liver (5).

The paper presented here describes a method for the preparation of isolated human liver cells and also describes the separation of these cells into pure parenchymal and non-parenchymal cell suspensions. A partial characterisation of these cells is also reported.

\section{Materials and Analytical Methods \\ Chemicals and Reagents}

Collagenase (EC 3.4.24.3), type II, was kindly supplied by Boehringer, Mannheim. Hyaluronidase (EC 3.2.1.35), type I, was obtained from Sigma. Calbiochem served as a source of pronase, B grade, while deoxyribonuclease I (EC 3.1.4.5) was purchased from Worthington. ${ }^{125}$ I-labelled porcine insulin was obtained from Hoechst. The insulin was routinely purified using the talc technique as described by Cuatrecasas (12). Metrizamide was purchased from Nyegaard \& Co A/S, Oslo. Bovine albumin, fraction V Pentex, was obtained from Miles Laboratories. Trypan blue stain, $4 \mathrm{~g} / 1$ in saline solution, was purchased from GIBCO. All other chemicals were commercial preparations of analytical grade.

\section{A naly tical Methods}

After appropriate periods of incubation of the liver cells at $37^{\circ} \mathrm{C}$, glucose (13) and lactate (14) were determined enzymatically. The incubation was stopped by adding $0.1 \mathrm{ml}$ of $300 \mathrm{~g} / \mathrm{l}$ perchloric acid to $0.9 \mathrm{ml}$ of the cell suspension. After centrifugation (Eppendorf centrifuge, model 3200, $2 \mathrm{~min}$ ) the supernatants were neutralized with solid $\mathrm{KHCO}_{3}$. The centrifugation was repeated and glucose and lactate determined in the clear supernatants. Glycogen was assessed according to Seifter's method (15). Protein was estimated by the Folin-phenol colorimetric method (16), using crystallized bovine serum albumin as standard. Insulin degradation was measured by the lack of trichloroacetic acid precipitability $(17,18) .{ }^{125}$ I-labelled insulin at $0.5 \mathrm{nmol} / 1$ was exposed to parenchymal human liver cells, suspended in $600 \mu \mathrm{l}$ of a modified Krebs-Ringer phosphate buffer (19), $\mathrm{pH} 7.5$, containing $10 \mathrm{~g} / \mathrm{l}$ bovine serum albumin. After separation from the cells (Beckman Microfuge B, 2 min), the insulin in the medium was precipitated by $100 \mathrm{~g} / 1$ trichloroacetic acid (final concentration). After centrifugation (Microfuge $\mathrm{B}, 3 \mathrm{~min}$ ) aliquots of the supernatant were taken for the measurement of ${ }^{125}$ I activity.

Studies of binding of ${ }^{125}$ I-labelled insulin to isolated parenchymal liver cells were performed at $30^{\circ} \mathrm{C}$ for $30 \mathrm{~min}$. Approximately 500000 cells were incubated in $500 \mu \mathrm{l}$ of a modified Krebs-Ringer phosphate buffer (19), pH 7.5, containing $10 \mathrm{~g} / 1$ bovine albumin. The incubation mixture contained ${ }^{125}$ I-labelled insulin at $0.3 \mathrm{nmol} / 1$ and unlabelled insulin at various concentrations from $1 \mathrm{nmol} / 1-10 \mu \mathrm{mol} / \mathrm{l}$. The incubation was terminated by rapidly separating the cells from the medium by centrifugation (Microfuge $\mathrm{B}, 10 \mathrm{~s}$ ). The supernatant was carefully sucked off. The pellet was suspended in $100 \mu \mathrm{l}$ of ice-cold modified Krebs-Ringer phosphate buffer, containing $1 \mathrm{~g} / \mathrm{l}$ bovine serum albumin. The suspended cells were then separated by centrifugation (Microfuge $\mathrm{B}, 3 \mathrm{~min}$ ) through a cushion of $200 \mu \mathrm{l}$ of icechilled buffer, placed in a $400 \mu$ l Beckman centrifuge tube. The tip of the centrif uge tube was pinched off and the radioactivity counted.

\section{Methodology and Results}

Patients

The livers were taken during routine human donor nephrectomies. The standards of organ transplantation require viable organs from physically healthy patients up to the age of 40 , who died mostly after severe traumatic brain injury.

\section{Hepatectom y}

Immediately after nephrectomy, the common bile duct was canulated and the common hepatic artery ligated. A cannula was inserted into the portal vein, and in situ perfusion commenced with $4-7^{\circ} \mathrm{C}$ cold Collin's solution. After perfusion with $1500 \mathrm{ml}$ Collin's solution, the various hepatic ligaments and the vascular attachments were excised completely and the perfusion continued extracorporeally with an additional $2000 \mathrm{ml}$ Collin's solution.

\section{Perfusion Apparatus}

The perfusion apparatus remotely resembles that described by Hems et al. (20) for rat liver perfusion. The design of the apparatus can be seen in Figure 1. The pre-pump reservoir (polyvinyl-chloride, $450 \times 400 \times 270 \mathrm{~mm}$ ), the filter unit (lucite, $150 \mathrm{~mm}$ in diameter, pore size $150 \mu \mathrm{m}$ ), the water heater, the pre-liver reservoir (Pyrex glass, capacity $1 \mathrm{l}$ ) and the bubble trap (Pyrex glass, capacity $250 \mathrm{ml}$ ) were manufactured in the workshop of the institute. The roller pump (Polystan HLM, model MP, modification type 259) was purchased from Polystan A/S, Herlev, Denmark. The LandèEdwards membrane oxygenators, model 5110 , size $1 \mathrm{~m}^{2}$ each, were obtained from Edwards Laboratories, Santa Ana, California, USA.

\section{Perfusion Procedure}

The liver was pre-perfused in vitro with $40 \mathrm{l}$ of calcium-free Krebs-Ringer phosphate buffer, $\mathrm{pH} 7.4$, which was not recirculated, but discarded. Following this, the perfusion medium was changed and the liver was perfused with $10 \mathrm{l}$ of calcium-free Krebs-Ringer hydrogencarbonate buffer, $\mathrm{pH} 7.4$, without recirculation. The outflow of the pre-pump reservoir was then directed back to the pump and recirculating perfusion of the organ was performed at $37^{\circ} \mathrm{C}$ for $45 \mathrm{~min}$ with 61 of calciumfree Krebs-Ringer hydrogencarbonate buffer, containing $500 \mathrm{mg} / \mathrm{l}$ of collagenase and $150 \mathrm{mg} / \mathrm{l}$ of hyaluronidase. The effective hydrostatic perfusion pressure was equivalent to approximately $20-25 \mathrm{~cm}$ of medium (i. e. the difference in

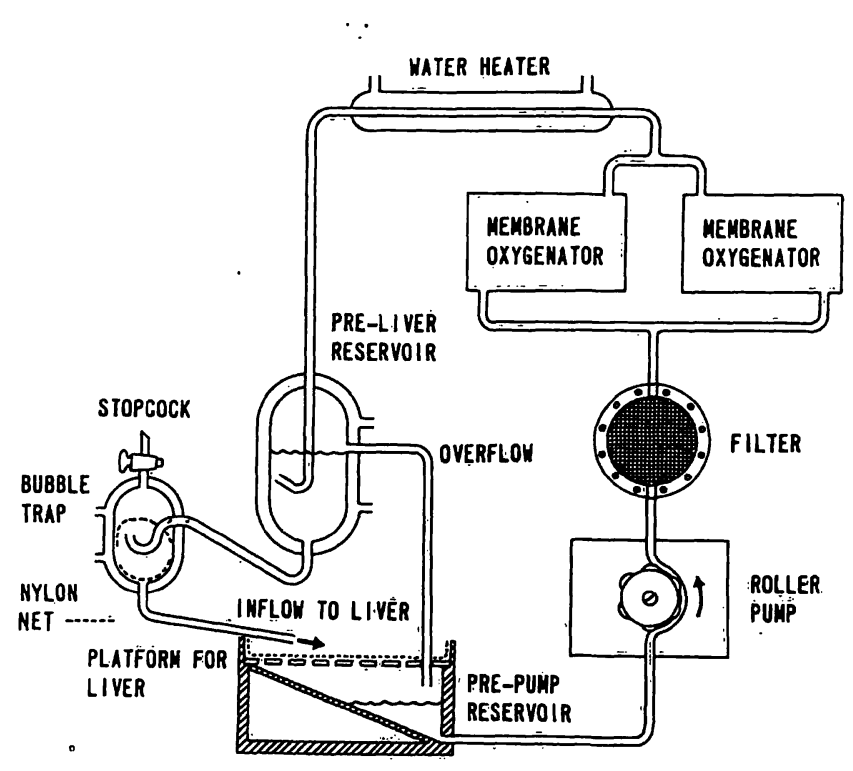

Fig. 1. Schematic diagram of the perfusion apparatus used for human liver. 
height between the overflow of the preliver reservoir and the surface of the liver). After 20-30 min, the consistency of the liver became soft, but the capsule of the organ remained tight. At that stage the liver was carefully massaged in order to improve the micro-circulation of the organ. The liver was removed at the end of $45 \mathrm{~min}$ of perfusion.

\section{Preparation of Cell Suspensions}

The organ was placed in an ice-chilled, commercially available plastic dish. The gall-bladder and all vascular and connective tissue were quickly removed. Thereafter, 21 of the perfusion medium were added and the liver gently minced with scissors. At this point the preparation contained isolated hepatocytes, clumps and strands of cells, cell debris and unbroken tissue fragments. The preparation was transferred to siliconized 10 l-beakers and the rest of the perfusion medium added. The cells were suspended by gently stirring at $70 \mathrm{rev} . / \mathrm{min}$ with a motordriven T-bar. The temperature of the suspension was maintained at $37^{\circ} \mathrm{C}$. After 15 min of stirring, the contents of the beakers were filtered through a single layer of nylon gauze of $150 \mu \mathrm{m}$ pore size. The cells were sedimented for $4 \mathrm{~min}$ at $500 \mathrm{rev} / \mathrm{min}$ in a Heraeus Christ centrifuge, type UJ 3S. The supernatants from this step and the following centrifugations were removed and pooled. Microscopic examination of the supernatants revealed non-parenchymal cells, some intact but predominantly damaged parenchymal cells and cell debris. Homogeneous non-parenchymal cell suspensions were prepared from this pool by the procedure described below.

\section{Parenchymal cells}

The sediment of the first low-speed centrifugation step consists mainly of parenchymal liver cells. These were washed twice in $150 \mathrm{ml}$ wash solution, i. e. Krebs-Ringer phosphate buffer, containing $25 \mathrm{~g} / 1$ bovine serum albumin. The cells were gently dispersed in the wash-solution. After each washing, the cells were sedimented at $500 \mathrm{rev} . / \mathrm{min}$ for $4 \mathrm{~min}$ in the centrifuge specified above. The final pellet was weighed and resuspended in Krebs-Ringer hydrogencarbonate buffer $(1: 10, \mathrm{w} / \mathrm{v})$.

\section{Non-parenchymal cells}

The preparation of pure non-parenchymal cell suspensions was achieved by the use of pronase and subsequent isopycnic centrifugation of the cell suspension on metrizamide gradients. The pooled supernatants of the first centrifugation step and the washings were centrifuged for $8 \mathrm{~min}$ at $1800 \mathrm{rev} . / \mathrm{min}$ in a Heraeus-Christ centrifuge, type UJ3S. A portion of the sediment (approximately $15 \mathrm{~g}$ of wet weight) was suspended in $400 \mathrm{ml}$ of Krebs-Ringer hydrogencarbonate buffer containing $2 \mathrm{~g} / \mathrm{l}$ of pronase and $10 \mathrm{mg} / 1$ of deoxyribonuclease. The mixture was transferred to 6 siliconized $250 \mathrm{ml}$ Erlenmeyer flasks, which were shaken at $37^{\circ} \mathrm{C}$ for $30 \mathrm{~min}$ in an atmosphere of $95 \% \mathrm{O}_{2}$ and $5 \% \mathrm{CO}_{2}$. Pronase is known to digest parenchymal cells from mouse and rat liver to unidentifyable debris, while it leaves non-parenchymal cells virtually intact $(7,8,10,11,21)$. After the incubation procedure, the suspension was filtered through a single layer of nylon gauze $(150 \mu \mathrm{m}$ pore size). The filtrate was then centrifuged at $1800 \mathrm{rev} . / \mathrm{min}$ for $8 \mathrm{~min}$. The sediment was suspended in wash solution containing $0.01 \mathrm{~g} / \mathrm{l}$ deoxyribonuclease. After centrifugation (1800 rev./min, $8 \mathrm{~min}$ ) the supernatant was discarded, the cell pellet resuspended in the same medium and washed twice. Finally, the cells were dispersed in a slightly hypotonic ( $260 \mathrm{mosmol} / \mathrm{l})$ buffer, $\mathrm{pH} 7.6$, and then mixed with varying amounts of buffered metrizamide solution as described in detail by Munthe-Kaas (11). Diffusion generated gradients were formed by Stone's method (22). The linear metrizamide gradients containing the cells (approximately $300 \mathrm{mg}$ of wet weight of cells per individual tube) were centrifuged at $4^{\circ} \mathrm{C}$ for $20 \mathrm{~min}$ in a Beckman SW 41 rotor at 8000 rev./ min. The non-parenchymal cells which were distributed heterogeneously in the upper half of the gradient (density $<1.11$ $\mathrm{kg} / \mathrm{l}$ ) were collected and pooled. A narrow band of cells, sedimenting in the inferior region of the gradient, contained mainly erythrocytes. This fraction and the pellet (cell debris) were discarded. The pooled non-parenchymal cell fractions were diluted $(1: 2, v / v)$. with calcium-free Krebs-Ringer phosphate buffer and centrifuged for $5 \mathrm{~min}$ at $2200 \mathrm{rev} . / \mathrm{min}$ in a Heraeus:
Christ centrifuge, type UJl. The cell pellet was washed in the same medium and then resuspended in Krebs-Ringer hydrogencarbonate buffer $(1: 10, \mathrm{w} / \mathrm{v})$.

\section{Appearance of Cell Suspensions}

\section{Parenchymal cells}

Figure 2 shows the typical spherical shape of isolated parenchymal human liver cells. The cell population consisted nearly exclusively of morphologically intact, free parenchymal cells. Non-parenchymal cells were almost completely absent in this preparation. The viability of the purified parenchymal cells, accessed by trypan blue staining, ranged between 85 and $95 \%$.

\section{Non-parenchymal cells}

A typical suspension of non-parenchymal cells is shown in Figure 3. Parenchymal cells were completely absent

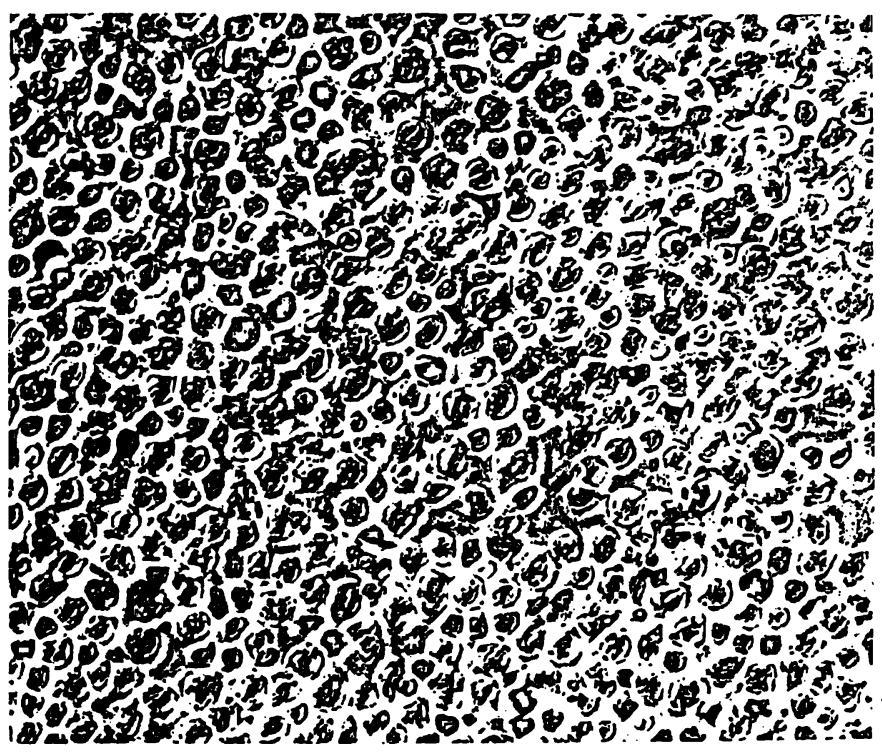

Fig. 2. Phase-contrast micrograph of isolated parenchymal human liver cells (500 $\times$ magnification).

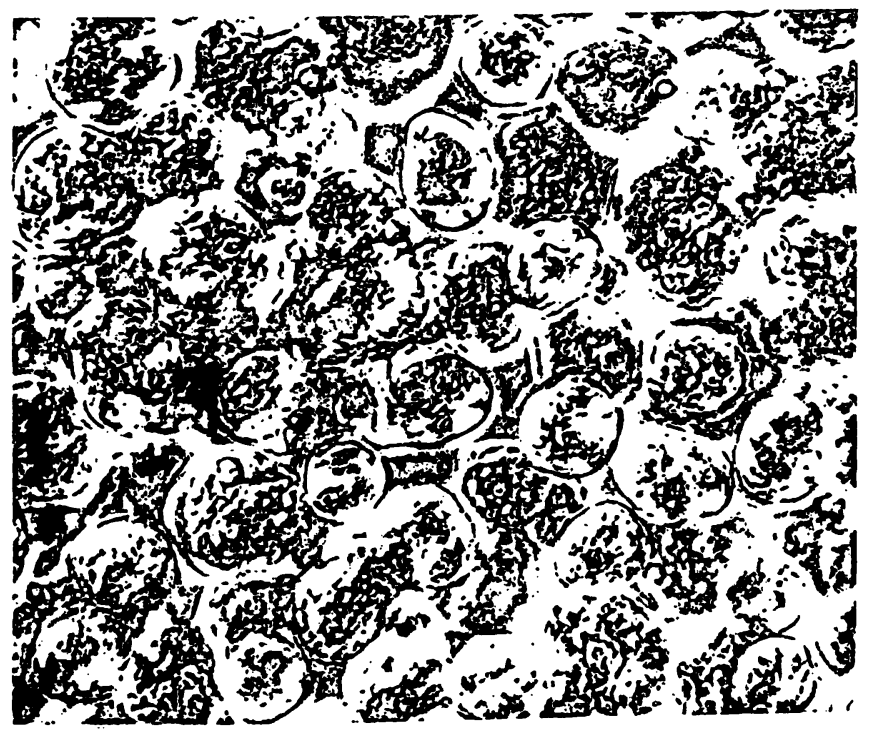

Fig. 3. Phase-contrast micrograph of isolated non-parenchymal human liver cells $(320 \times$ magnification). 
in the final preparation. Microscopic examination at higher magnification (not shown) revealed that this fraction consisted of several types of non-parenchymal cells, mainly Kupffer and endothelial cells. The percentage of viable cells, estimated by the trypan blue exclusion test, amounted to about $90 \%$.

\section{Studies on Carbohydrate Metabolism}

Compared with metabolic studies using isolated liver cells from rigorously controlled experimental animals, detailed studies on the metabolism of human liver cells are complicated to a certain degree by the fact that the nutritional state of the liver donors cannot be influenced by the investigators. For this reason, certain metabolic performances, like gluconeogenesis and glycogen synthesis, must differ from one patient to another. For the purpose of this report, namely to demonstrate the metabolic activity of enzymatically isolated human liver cells, the related data on gluconeogenesis and glycogen synthesis of the hepatocytes of a 32 year old man were selected who died of a severe traumatic brain injury.

\section{Glucose formation of parenchymal cells}

Studies on glucose formation of isolated parenchymal human liver cells are summarized in Figure 4. The addition of $L$-alanine, $L$-lactate, pyruvate and fructose at $10 \mathrm{mmol} / \mathrm{l}$ differentially enhanced glucose production. $L$-lactate and pyruvate served as better precursors for glucose synthesis than did $L$-alanine. As in the perfused rat liver, the rate of glucose formation is almost the same with $L$-lactate and pyruvate.

\section{Glucose consumption of non-parenchymal cells}

Non-parenchymal human liver cells were not capable of gluconeogenesis but utilized glucose at high rates. When

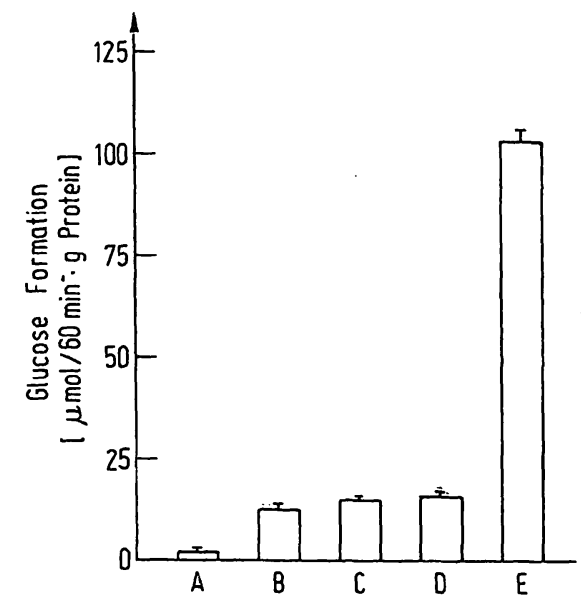

Fig. 4. Glucose formation from various substrates in isolated parenchymal human liver cells ( $3.25 \mathrm{mg}$ protein) were incubated with $1 \mathrm{ml}$ Krebs-Ringer hydrogen-carbonate buffer containing $10 \mathrm{mmol} / 1$ substrate for $60 \mathrm{~min}$.

A) no substrate, B) $L$-alanine, C) $L$-lactate, D) pyruvate, E) fructose.

The results are given as mean \pm SEM of 5 individual incubations. incubated at $37^{\circ} \mathrm{C}$ with $5.5 \mathrm{mmol} / 1$ glucose under an atmosphere comprising $95 \% \mathrm{O}_{2}$ and $5 \% \mathrm{CO}_{2}$, nonparenchymal cells consumed $17.13 \pm 0.01 \mu \mathrm{mol} / \mathrm{g}$ wet weight of glucose per hour. In these aerobic cells, about one third of the utilized glucose was converted to lactate, i. e. $11.62 \pm 0.27 \mu \mathrm{mol} / \mathrm{g}$ wet weight of lactate formed per hour.

\section{Glycogen synthesis of parenchymal cells}

The glycogen content of unincubated parenchymal human liver cells amounted to $493.85 \pm 1.87 \mathrm{mg} / \mathrm{g}$ protein. The intracellular glycogen levels were significantly lowered by $21.25 \pm 1.06 \%$, when the cells were incubated without any substrates. However, $L$-alanine, $L$-lactate and fructose at $1.0 \mathrm{mmol} / \mathrm{l}$ caused a significant increase in glycogen content. As can be seen in Figure 5, glycogen synthesis was almost the same with $L$-alanine and $L$-lactate as the precursors. The highest rates of glycogen formation were obtained when fructose was added.

\section{Degradation and Binding of Insulin by Parenchymal Cells}

The time course of ${ }^{125}$ I-labelled insulin degradation by parenchymal liver cells is shown in Figure 6. At a low cell concentration of about $5 \times 10^{5}$ cells per reaction, only a small proportion of the labelled hormone was degraded. The binding experiments were conducted at this low cell concentration, with $30 \mathrm{~min}$ incubation at $30^{\circ} \mathrm{C}$. Under these conditions, degradation of insulin usually did not exceed $5 \%$, as measured by the trichloroacetic acid-precipitation method (Fig. 7). Parenchymal human liver cells demonstrated binding of ${ }^{125}$ I-labelled insulin, which could be inhibited by unlabelled insulin

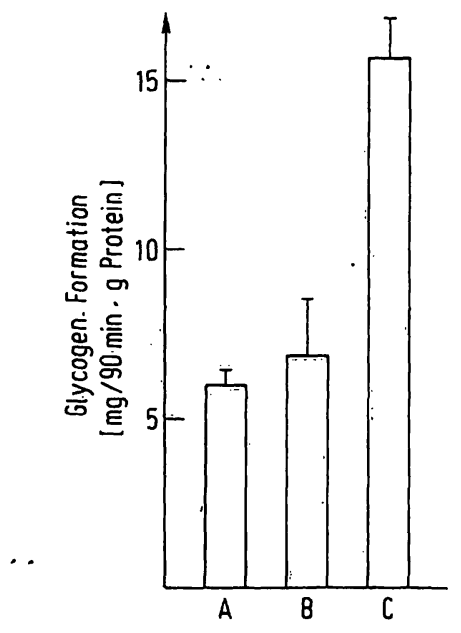

Fig. 5. Synthesis of glycogen by isolated parenchymal human liver cells incubated with different substrates at $10 \mathrm{mmol} / \mathrm{l}$.

- A) $L$-alanine, B) $L$-lactate, C) fructose. Isolated parenchymal liver cells ( $9.75 \mathrm{mg}$ protein) were incubated in $3 \mathrm{ml} \mathrm{Krebs-Ringer,} \mathrm{hydrogencarbonate}$ buffer for $90 \mathrm{~min}$ at $37^{\circ} \mathrm{C}$. Values are mean \pm SEM of 5 individual observations. 


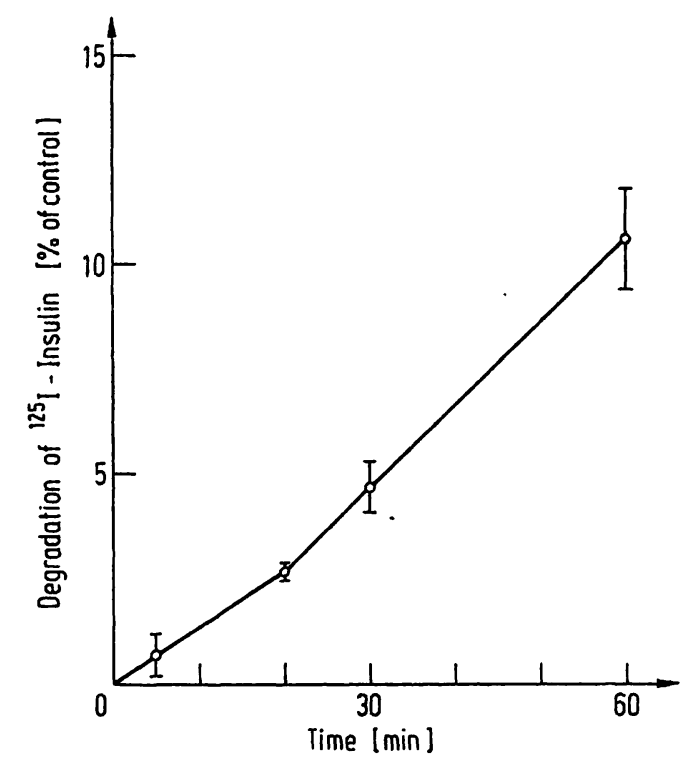

Fig. 6. Time course of degradation of insulin by parenchymal human liver cells. ${ }^{125} \mathrm{I}$-labelled insulin at $0.5 \mathrm{nmol} / 1$ was exposed to parenchymal cells $\left(5.02 \times 10^{5}\right.$ per reaction $)$ at $30^{\circ} \mathrm{C}$ for the indicated times. After separation from the cells, the insulin in the medium was precipitated by $100 \mathrm{~g} / 1$ trichloroacetic acid. The radioactivity in the supernatant was counted, corrected for trichloroacetic acid soluble ${ }^{125}$ I activity in control tubes (cells omitted) and calculated as percentage of the trichloroacetic acidprecipitable radioactivity in the controls. Bars represent S. D. $(n=4)$.

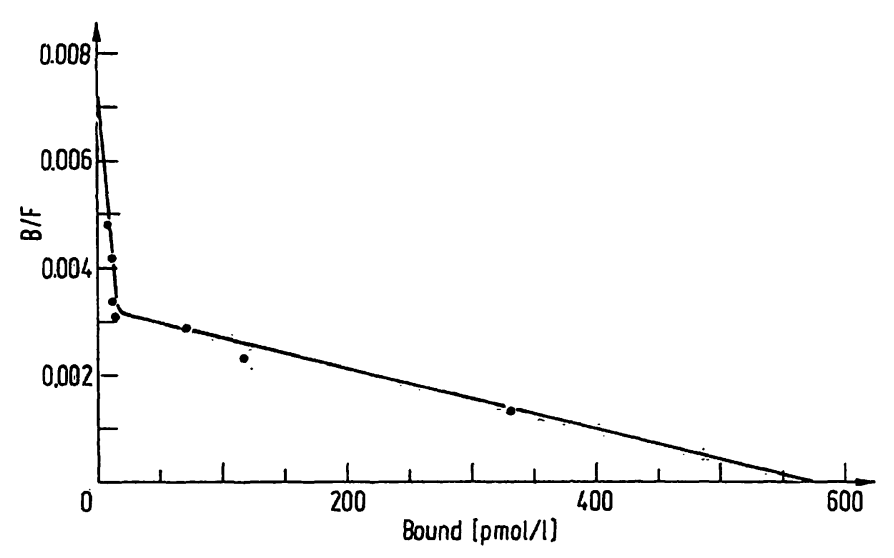

Fig. 7. Scatchard analysis of insulin binding to isolated parenchymal human liver cells. Approximately 500000 cells were incubated in $500 \mu \mathrm{l}$ of phosphate buffer at $30^{\circ} \mathrm{C}$ for 30 min. The incubation mixture contained ${ }^{125} \mathrm{I}$ labelled insulin at $0.3 \mathrm{nmol} / 1$ and unlabelled insulin at various concentrations from $1 \mathrm{nmol} / \mathrm{l}-10 \mu \mathrm{mol} / \mathrm{l}$. All data used for this plot are the means of quintuple determinations and were corrected for non-specific binding, j. e. binding of ${ }^{125}$ I-labelled insulin in the presence of $10 \mu \mathrm{mol} / \mathrm{l}$ unlabelled insulin.

at various concentrations. Binding of ${ }^{125} \mathrm{I}$ labelled insulin in the presence of $10 \mu \mathrm{mol} / \mathrm{l}$ unlabelled insulin was considered to be nonspecific (17). The binding datā were corrected for nonspecific binding and analysed according to Scatchard (23). As can be seen in Figure 7, a biphasic plot was obtained, which may indicate the presence of a heterogeneous population of binding sites.
The data may be presented by two classes of sites: a high affinity - low capacity site and a low affinity high capacity site. Approximations for the binding data of the two orders of sites were made by manual curve fitting (24). The high affinity site had a dissociation constant of about $6.6 \mathrm{nmol} / 1$ and a binding capacity of approximately 16000 insulin molecules per cell. Assuming a mean cell surface area of $1765 \mu \mathrm{m}^{2}$, the concentration of binding sites per unit of surface area amounted to 9 sites $/ \mu \mathrm{m}^{2}$. The low affinity site had a dissociation constant of $0.37 \mu \mathrm{mol} / 1$ and a capacity of about 664000 insulin molecules per individual cell. Expressed per unit of surface area, the number of binding sites amounted to approximately 380 sites $/ \mu \mathrm{m}^{2}$.

\section{Discussion}

The techniques for obtaining isolated parenchymal and non-parenchymal human liver cells, described in the present paper, yield highly purified preparations of both cell populations. The isolated cells were viable as judged by microscopic appearance, trypan blue exclusion, and metabolic performance, as well as the preservation of insulin receptors on the cell membrane. Our results demonstrate the integrity of the energy requiring pathways of gluconeogenesis and glycogen synthesis in parenchymal human liver cells. The similarity of the rates of glucose formation from pyruvate and lactate indicates that no major leakage of the cytoplasmic lactate dehydrogenase (EC 1.1.1.27) did occur. However, the rates of gluconeogenesis in parenchymal human liver cells are significantly lower than those of rat liver cells (4). The question of whether or not this reflects a real species difference remains to be elucidated. It is quite possible, that differences in the nutritional state and, or the stress situation in the moribund liver donor may be responsible for the observed difference in the metabolic performance of the isolated hepatocytes from rat and man.

The rate of glucose uptake of non-parenchymal human liver cells was very similar to that of non-parenchymal liver cells isolated from rats (25). However, non-parenchymal rat liver cells produced significantly more lactate under aerobic conditions than did non-parenchymal cells from human liver (25).

The dissociation constants $\left(\mathrm{K}_{\mathrm{d}}\right)$ of high and low affinity insulin binding by parenchymal human liver cells were determined as $6.6 \mathrm{nmol} / 1$ and $0.37 \mu \mathrm{mol} / 1$, respectively.

For comparison, Gammeltoft \& Gliemann (18) reported receptor binding of ${ }^{125}$ I-labelled insulin by fat cells from rats with a $\mathrm{K}_{\mathrm{d}}$ of $3 \mathrm{nmol} / \mathrm{l}$, Kono \& Barham (26), using the same model, calculated a value of $7 \mathrm{nmol} / 1$. In both studies only a single class of receptors could be demonstrated which strongly resemble the high affinity sites of parenchymal human liver cells. Marinetti et al. (27) found three different orders of receptor sites for insulin 
in rat liver plasma membranes $\left(\mathrm{K}_{\mathrm{d} 1} 0.1 \mathrm{nmol} / 1, \mathrm{~K}_{\mathrm{d} 2}\right.$ $\left.0.24 \mu \mathrm{mol} / 1, K_{\mathrm{d} 3} 7.7 \mu \mathrm{mol} / 1\right)$. The second class of receptor sites is very similar to the low affinity binding site $\left(\mathrm{K}_{\mathrm{d}} 0.37 \mu \mathrm{mol} / \mathrm{l}\right)$ reported in this paper.

Analysing the data of ${ }^{125}$ I-labelled insulin binding, the common assumption was made that the biphasic Scatchard plot may indicate the presence of 2 orders of binding sites. However, the concave upward curve shown in figure 7 could also be interpreted in terms of negative cooperativity $(28,29)$. One has to realize that in the presence of cooperative mechanisms the values of the dissociation constant and the number of binding sites derived from a Scatchard analysis do not have their usual precise physico-chemical meaning.

\section{Acknowledgements}

This investigation was supported by a research grant from the Deutsche Forschungsgemeinschaft (Sonderforschungsbereich 113, Diabetesforschung Düsseldorf).

Valuable technical assistance was given by Miss Claudia Nathrath and Mrs. Angelika Guth.

\section{References}

1. Howard, R. B., Lee, J. C. \& Pesch, L. A. (1973), J, Cell. Biol. $37,642-658$.

2. Berry, M. N. \& Friend, D. S. (1969), J. Cell. Biol. 43, 506520.

3. Seglen, P. O. (1973), FEBS Letters 30, 25-28.

4. Bojar, H., Balzer, K., Reiners, K., Basler, M., Reipen, W. \& Staib, W. (1975), this j. 13, 25-30.

5. Guillouzo, A., Oudea, P., le Guilly, Y., Oudea, M. C., Lenoir, P. \& Bourel, M. (1972), Exp. Mol. Pathol. 16, 1-15.

6. Sweat, F. W. \& Hupka, A. (1971), Biochem. Biophys. Res. Commun. 44, 1436-1442.

7. Roser, B. (1968), J. Reticuloendothelial Soc. 5, 455-471.

8. Mills, D. M. \& Zucker-Franklin, D. (1969), Am. J. Pathol. 54, 147-155.

9. Lentz, P. E. \& di Luzio, N. R. (1.971), Exp. Cell. Res. 67, $17-26$.

10. Berg, T. \& Blix, A. S. (1973), Nature (New Biol.) 245, $239-240$.

11. Munthe-Kaas, A. C. \& Seglen, P. O. (1974), FEBS Letters $43,252-256$.

12. Cuatrecasas, P. (1971), Proc. Nat. Acad. Sci. U.S.A. 68, 1264-1268.

13. Werner, W., Rey, H. G. \& Wielinger, H. (1970), Z. Anal. Chem. 252, 224-228.

14. Hohorst, H. J. (1962), Methoden der enzymatischen Analyse, $1^{\text {st }}$ ed. (Bergmeyer, H. U., ed.) pp. 266-270. Verlag Chemie, Weinheim.

15. Seifter, S., Dayton, S., Novic, B. \& Muntwyler, E. (1950), Arch. Biochem. Biophys. 25, 191-200.

16. Lowry, O. H., Rosebrough, A. L., Farr, A. L. \& Randall, R. J. (1951), J. Biol. Chem. 193, 265-275.
17. Freychet, P., Kahn, R., Roth, J. \& Neville, D. M. (1972), J. Biol. Chem. 247, 3953-3961.

18. Gammeltoft, S. \& Gliemann, J. (1973), Biochim. Biophys. Acta 320, 16-32.

19. Kahn, C. R., Neville, D. M. \& Roth, J. (1973), J. Biol. Chem. 248, 244-250.

20. Hems, R., Ross, B. D., Berry, M. N. \& Krebs, H. A. (1966), Biochem. J. 101, 284-292.

21. Knook, D. L., Sleyster, E. C. \& Noord, M. J. (1975), Cell Impairment in Aging and Development (Cristofalo, K. J. \& Holeckowa, E., eds.) pp. 155-169. Plenum Publishing Corporation, New York.

22. Stone, A. B. (1974), Biochem. J. 137, 117-118.

23. Scatchard, G. (1949), Ann. N. Y. Acad. Sci. 51, 660-672.

24. Berson, S. A. \& Yalow, R. S. (1959), J. Clin. Invest. 38, $1996-2016$.

25. Bojar, H., Basler, M., Bàzer, K. \& Staib, W. (1976), Proceedings of FEBS Advanced Course No. 38. North-Holland Publishing Co., Amsterdam (442-443).

26. Kono, T. \& Barham, F. W. (1971), J. Biol Chem. 246, 6210-6216.

27. Marinetti, G. V., Schlatz, L. \& Reilly, K. (1972), Insulin Action (Fritz, I. B., ed.) pp. 207-296. Academic Press, New York.

28. Koshland, D. E. (1970), The Enzymes, 3rd ed., Vol 1 (Boyer, P. D., ed.) pp. 341-396. Academic Press, New York and London.

29. De Meyts, P., Roth, J., Neville, D. M., Gavin, J. R. \& Lesniak, M. A. (1973), Biochem. Biophys. Res. Commun. 55, 154161 . 